\title{
ROLE OF THE TECHNOLOGIST IN THE MODERN WORLD
}

\author{
Extracted from Professor P. M. S. Blackett's Presidential Address to the Royal \\ Society at the anniversary meeting on November 30, 1966*
}

I WANT to express some personal views on the problems of the place of engineers and technologists in contemporary British life and the relations of the Royal Society to technology and engineeering. It seems generally agreed that in Britain engineers and technologists do not receive the public esteem which their ability and importance to the community would justify, and that other advanced countries are better placed in this respect. As a result, so it is often argued, not enough first class scientists and technologists enter industry, and this leads to some industries in Britain which are less than the best. This in turn leads to inadequate exports and so contributes to the present financial crisis. Assuming the general truth of these facts, then of course their origin must be highly complex and must include such facts as the training which engineers and scientists receive at the universities, their salary levels for industry, and more broadly the managerial structure of firms and industry as a whole. It would follow then that any lack of public esteem accorded to engineers is but a symptom of some deep underlying national failings which need urgent attention. Even so, it is reasonable to consider whether there are not some steps which could be taken to attempt to raise the esteem in which technologists and engineers are now held, while also energetically tackling the underlying troubles.

The Royal Society has, in the past, included in the fellowship such outstanding engineers as Smeaton Rennie, James Watt, Brunel (father and son), R. Stephenson, Siemens, Parsons, S. Z. de Ferranti and Sir William Stanier, to mention only a few. It is my personal view, however, that in recent decades the Society has been somewhat remiss in not recognizing more engineers and applied scientists by admission to the fellowship. I gain the impression that the level of ability, originality and eminence required of an engineering designer, for example, to be admitted to the fellowship has been disproportionately higher than that required of a research scientist. I feel that the imbalance between these two levels has been detrimental to the Society and to Britain as a whole.

The situation in this respect, however, is changing. For the past three years this problem of giving adequate recognition to engineers and technologists has been seriously discussed within the Society. One outcome was the raising in 1964 of the number of candidates elected each year from twenty-five to thirty-two, with the explicit object of using some of these seven additional places for applied scientists and engineers. As a result, there is no doubt that the fraction of the fellowship consisting of technologists is rising to an important extent. I hope to see this process continued until the imbalance which I believe to exist within the Society between engineering designers and research scientists is rectified. Active discussions are in progress between the Council of the Engineering Institutions and the Society as to what further action might bring national advantage.

It is, I think, generally conceded that one field of activity in which the scientific academies of the world can play an especially important part lies in the international relations of science. In recent years the Royal Society has been very active in promoting scientific contact and interchange between Britain and the Eastern European countries, and much valuable collaboration has resulted. Special efforts wore made successfully to open up relations with China, and as a result there are now a number of Chinese postgraduate students at work in British labor-

* See p. 974 for awards of medals. atories. Little has been done, however, to stimulate exchanges with Western Europe, on the not unreasonable assumption that these looked after themselves. A little investigation has shown, however, that this was not so. A sample survey of a few British university science departments showed that the number of postdoctorate students from Europe working in Britain was less than a fifth of those from the United States. A still greater ratio must exist between the numbers of British postdoctorate students working in the United States and in Europe.

After much consideration within the Royal Society, it was decided to attempt to raise funds adequate to make a notable increase in the scientific interchanges within Europe both by long and short visits and the organization of conferences. The foreign secretary of the Society undertook the process of making personal contacts throughout Europe with savants and organizations with the idea of working out common policies. While these exploratory contacts were being pursued, however, the Society felt it would like to start actual interchanges.

The Society has already received a grant of $£ 3,000$ and has been promised $£ 10,000$ a year for 3 years from the Wates Foundation, and in addition $£ 10,000$ over 7 years from the Pergamon Press. The Society is deeply grateful for these gifts, and is energetically preparing ways and means of using this money to start the promotion of two-way interchanges and conferences in Eupope. The Society recognizes clearly that these steps are only a beginning and that for Europe to make a substantial step forward towards a more integrated structure of science would mean much money and much organizing activity in all European countries which share these aspirations. To facilitate discussion within the Society of all the manifold problems relative to the international relations of science, the Council has created a new Committee on Intornational Relations to advise it on all these matters.

At the present time the Society has two direct working contacts with those parts of the government machine which deal with the international relations in science. One is a Standing Committee on International Scientific Relations set up by, and reporting to, the Council for Scientific Policy. This committee, of which Sir Harrie Massey is chairman, has already become an important link in the machinery for discussion and for feeding well considered advice into the administrative machine in Whitehall; reciprocally, of course, it makes for greater understanding among scientists of the problems of the Ministers who are concerned with the international relations of science. The second point of contact is a committee to advise the Ministry of Overseas Development on the scientific and technological aspects of the Unesco programmes. At present, Sir William Slater is chairman. These two bodies provide direct contact between the Society and the Whitehall administrative machine. In addition, all five of the research councils have each invited the Society to nominate a fellow to attend their meetings of the council as an assessor.

These growing contacts between the Society and the government administrative machine in Whitehall seem to me to be of great importance for tho future of British science. I would fully expect, and greatly welcome, the further extension of such working contacts. The more the Society becomes involved in Whitehall, however, so in my view does it become of still greater importance for the Society to have a firm independent base from which to operate, which is adequately financed from private sources over the long term. 